\title{
A Descriptive Study on the Seventh Grade students' Reading Comprehension Achievement at SMP SUNAN GIRI CLURING in the 2013/2014 Academic Year
}

\author{
Tersia Dara Yuanita \\ English Educational Departement, Universitas PGRI Banyuwangi
}

\author{
Received : Tuesday, March 13, 2018 \\ Revised : Friday, March 16, 2018 \\ Accepted : Wednesday, March 28, 2018
}

\begin{abstract}
In this research, the researcher wanted to describe about the students' reading comprehension achievement. This research design was applied on descriptive quantitative research. The respondent was the seventh class students at SMP Sunan Giri CLuring in 2013/2014 Academic Year. The total respondent was 22 students from one class determined through population.
\end{abstract}

The primary data was a reading comprehension test as an achievement test in the form of multiple choices. The result was analyzed statistically in percentage then descriptively which presented the students' scores for their achievement in Literal Reading Comprehension, and Inferential Reading Comprehension. The secondary data was taken from the documentation and interview.

The results of the research showed that the seventh class students' achievement in reading comprehension is good $(73,4 \%)$. The details are good $(75,4 \%)$ for Literal Reading comprehension. And was fair $(67,2 \%)$ for Inferential Reading comprehension.

The students get the lowest achievement for Inferential Reading Comprehension and the highest achievement for Literal Reading Comprehension. The students need to improve their vocabulary in order to make them easier in reading comprehension especially for Inferential Reading Comprehension.

Keywords:Reading Comprehension, Achievement

\section{A. Introduction}

Reading comprehension is the ability to read text, process it and understand its meaning. And individual's ability to comprehend text is influenced by their tratis and skills, on fo which is the ability to make inferences. If word recognition is difficult, student use too much of their processing capacity to read individual words, which interferes with their ability to comprehend what is read. We define nreading comprehension as the process of simultaneously extracting and constructing meaning through interaction and involvement with written language. We use the words extracting and constructing to emphasize bot the importance 
and the insufficiency of the text as a determinant of reading comprehension. (Snow, 2002).

In the process of reading. Students have to understand the text, but the most important thing is they can comprehend the content of the text or the message of the reading text. The detail comprehension is necessary to get information of the reading text. The detailed comprehension is necessary in order to know the contents of the text.

Since the reading comprehension skill is the main focus on the teaching of English at Junior High School, it is necessary to conduct research to know the students achievement in reading comprehension. In this cas, the writer conducted the research entitled " A Descriptive Study on the Seventh Grade Students' Reading comprehension Achievement at SMP Sunan Giri Cluring in the 2013/2014 Academic Year.

Here, how is the the seventh grade students' reading comprehension achievement at SMP Sunan Giri Cluring in the 2013/2014 Academic Year? As the main question in this research. Which was it's objective was to describe the seventh grade students' reading comprehension achievement at SMP Sunan Giri Cluring in the 2013/2014 Academic Year.

Conducting this research would be significantly influenced to the students in order to motivate and increase their reading comprehension achievement and to get as much as information that the text given in real reading materials.

The research was limited on describe the condition and the result of reading comprehension in the seventh grade students of SMP Sunan Giri Cluring in 2013/2014 academic year. Which consisted of 22 students in it's class.

\section{B. Reading}

The main purpose of reading is to get information about anything, give motivation to the readers and understanding the meaning of the text. According to Anderson (Sofyah, 2011:10) the purpose of reading are:

\section{Reading for details and facts}

To acquire some inventions that have been done by the actor, what has been acted by the actor, what has happened to the characters, and soon. and summarize the things that have been done by the actor to reach his purpose.

\section{Reading for main ideas}

To find out the problems, what has happened to the actor, and summarize the things that have been done by the actor to reach his purpose.

\section{Reading for sequence or organization}

\section{Reading for inference}

To know what is happening in every part of the story.

To know why the actor acted in such ways, what is the author intended to the story or the reading, why there is a change to the actor, and so on 


\section{Reading for classify}

To find and know the things that are not unusual, what was funny in the story or passage, whether the actor was succeed, whether it is good for us to act like the actor, and so on

\section{Reading for valuate}

To find out whether the actor was succeed, whether it is good for us to act like the actor, and so on

\section{Reading to compare or contrast}

To find out how to change the character, how his life is different from the habits of life as we know, how the two stories have in common, and so on.

\section{Reading Comprehension}

Reading for comprehension should be the primary objective of reading process. It is also known as a difficult process to grasp the meaning of vocabulary or series of words highlighted in oral or printed form. It includes not only the ability to decode words but also the awareness of their meaning. Furthermore, comprehension and decoding skills combine to allow and individual to make sense of a printed text. In addition, once students are able to decode, formal instruction should be continued to make them understand what they had read. This will enhance students thinking and reading process. Thus, comprehension monitoring skilled and unskilled awareness in important to develop student reading skills.

Reading comprehension is not a single step or easily acquired. It is a very complex process that teacher find difficult to teach.

Eksay (Yossuke, 2011) stated that reading comprehension is viewed as the result from the four ways interaction between readers, text task and structured activity. Kee (Yossuke, 2011) explained that reading comprehension is a process. Instead, it is an activity two way process in which the reader and the text interacting each other. The reader test clues from the text against his knowledge to arrive at an understanding of the text acceptable to the reader.

In short, comprehension is an important aspect to develop student ability to read with understanding. Besides that, comprehension monitoring skill reader and non-skill reader are crucial because students are bale to engage appropriate methods to highlight their reading skills. Moreover, its give some insight to instructors or teachers that how unskilled and skilled learners engaged with the reading skills. It is important for teachers and instructors to know about reading processes and it will be discussed in the next sub topic.

Finally based on the experts stated before, researcher concluded that reading comprehension is the final products of combining some skills and reading process itself to identify the text structures to get the meaning to of the text comprehensively. In this research, reading comprehension referred to the degree of ability or the final product of reading process in finding literal comprehension and inferential comprehension. 


\section{Methodology}

This research was descriptive study as Ary (2002:558) states, descriptive research is a research that asks question about the nature, incidence, or distribution of variables; it involves describing but not manipulating variables.

The researcher chose SMP Sunan Giri Cluring were selected as the area of research by considering two reasons. First, the school principle officially permitted the researcher to administer the research. Second, as the result of interview with the English teacher, it was said that the teacher had difficulties in promoting students' reading comprehension achievement in descriptive text.

According Arikunto (2002:117), purposive method is employed by researcher to decide the area because of certain purposes. In this research, the researcher took the seventh grade student of SMP Sunan Giri Cluring as research area with the seventh grade students as population of this research. The researcher had 22 students, that's consist of 12 males and 10 females.

Primary data and secondary data were collected by certain methods. Primary data collected by using test, in this case was reading test that was given to students. It was collected in order to measure students' ability in comprehending reading material. The test result were analyzed then researcher infer students' reading comprehension to answer the general problem of this research.

Secondary data were administered by interview and documentation. Researcher interviewed the students, teacher and some other respondents were correlated to this research. The information dig from those respondents were used to support the result of primary data, in this interview was the ways how teaching grammar were taught in the classroom. Interview was conducted on May, 28 2014.

The last, documentation were needed in supporting the process of the research such as, list of English teacher, list of respondents, and school map. All those data were collected before and after researcher started the primary research.

\section{Data analysis}

\section{Research procedures}

In this research, there were two kind of collected data, qualitative data and quantitative data. The qualitative data was the record or note of information from respondents, students and English teacher. Kind of this data were analyzed by grouping the data then interpret them in order to draw conclusion.

Quantitative data were collected from reading comprehension test result, students' score. Analyzing those data were using the following formula.

$$
\sum=\frac{n}{N} \times 100 \%
$$

Notes:

$\Sigma=$ the percentage of the students' reading 


$\begin{aligned} \mathrm{n}= & \text { the scores of each indicator obtained by the } \\ & \text { students } \\ \mathrm{N}= & \text { the total score of the test items }\end{aligned}$

(Adapted from Cholisa, 2002:246)

The result of equation was consulted to the table of classification of the score levels, as shown in the following table:

\begin{tabular}{|c|l|}
\hline Score & Category \\
\hline $80-100 \%$ & Excellent \\
$70-79 \%$ & Good \\
$60-69 \%$ & Fair \\
$40-59 \%$ & Poor \\
$0-39 \%$ & Failed \\
\hline \multicolumn{2}{|c|}{ (Adapted from DEPDIKBUD, 1999, as quoted by Nurul Khotimah 2013:31) } \\
\hline
\end{tabular}

\section{Data presentation}

a. Qualitative Data

Qualitative data as it was said before, reported that: SMP Sunan Giri Cluring was founded in 1986. It is located on JL Raya Genteng 09 Phone (0333) 394102. the foundation that manages this school is LP. Ma'arif NU. it has $2040 \mathrm{~m} 2$ and building $600 \mathrm{~m} 2$. It has single class for each level.

SMP Sunan Giri facilitates with compure lab, office, multimedia class and parking lot both for students and teachers/school staff. Human resources of this school consist of teachers, school staff, librarian and gardeners.

The numbers of the students are 93 students in total. Seventh grader 22 students, eighth grader 29 students and ninth grader 39 students. Researcher determined the respondent and population of the research the seventh grader.

First interview was conducted with the English teacher, the interview intended to collect information about the teaching technique in reading comprehension. From the interview founded that the teacher has applied communicative or meaningfulness approach based on the English Curriculum 2006 and the point of expected in learning process is to communicate at functional level: communicate through spoken and written. The teaching process around the four English skills, which are reading, writing, speaking and integrally with the reading and writing skills. In the English teaching and learning process, the teacher used Indonesian more frequent than English.

b. Quantitative data

The result of the test shown in the following table:

\begin{tabular}{c|c|c|c|c|c}
\hline \multirow{3}{*}{ NO } & \multirow{2}{*}{$\begin{array}{c}\text { NAME } \\
\text { (INITIAL) }\end{array}$} & \multicolumn{2}{|c|}{$\begin{array}{c}\text { THE NUMBER OF } \\
\text { CORRECT ANSWER } \\
\text { FOR EACH INDICATOR }\end{array}$} & \multirow{3}{*}{$\begin{array}{c}\text { CORRECT } \\
\text { FONSWER }\end{array}$} & \multirow{2}{*}{ TOTAL } \\
\cline { 3 - 4 } & & LRC & IRC & & \\
\cline { 3 - 4 } & $\mathbf{1 5}$ ITEMS & $\mathbf{5}$ ITEMS & & \\
\hline 1 & $\mathrm{AM}$ & 10 & 5 & 15 & 75 \\
\hline 2 & $\mathrm{AF}$ & 9 & 5 & 14 & 70 \\
\hline
\end{tabular}




\begin{tabular}{c|l|c|c|c|c}
\hline 3 & A & 15 & 3 & 18 & 90 \\
\hline 4 & BH & 13 & 3 & 16 & 80 \\
\hline 5 & DIA & 13 & 3 & 16 & 80 \\
\hline 6 & IFB & 9 & 2 & 11 & 55 \\
\hline 7 & KC & 8 & 4 & 12 & 60 \\
\hline 8 & MH & 13 & 4 & 17 & 85 \\
\hline 9 & MKA & 12 & 2 & 14 & 70 \\
\hline 10 & MSA & 8 & 4 & 12 & 60 \\
\hline 11 & MSA & 11 & 3 & 14 & 70 \\
\hline 12 & MIK & 13 & 2 & 15 & 75 \\
\hline 13 & MMIF & 12 & 3 & 15 & 75 \\
\hline 14 & MRH & 10 & 3 & 13 & 65 \\
\hline 15 & MYA & 10 & 4 & 14 & 70 \\
\hline 16 & M & 12 & 4 & 16 & 80 \\
\hline 17 & NSN & 13 & 2 & 15 & 75 \\
\hline 18 & QA & 13 & 4 & 17 & 85 \\
\hline 19 & RA & 13 & 3 & 16 & 80 \\
\hline 20 & SJ & 9 & 3 & 12 & 60 \\
\hline 21 & VS & 12 & 3 & 15 & 75 \\
\hline 22 & VIR & 11 & 5 & 16 & 80 \\
\hline TOTAL & 249 & 74 & 323 & \\
\hline$\%$ & 75,4 & 67,2 & 73.4 & \\
\hline & & & & \\
\hline
\end{tabular}

LRC : Literal Reading Comprehension

IRC : Inferential reading Comprehension

Score : The total Number of each Students score

Score (\%) : The Average score of each indicator in each percentage

After the formulation of the quantitative data result, shown in the following table:

\begin{tabular}{c|l|l|l|l}
\hline No & \multicolumn{1}{|c|}{ Indicator } & $\begin{array}{c}\text { Score } \\
\text { Percentage }\end{array}$ & $\begin{array}{l}\text { Power } \\
\text { Grade }\end{array}$ & Interpretation \\
\hline 1 & $\begin{array}{l}\text { Literal Reading } \\
\text { Comprehension }\end{array}$ & $75,4 \%$ & $70 \%-79 \%$ & Good \\
\hline 2 & $\begin{array}{l}\text { Inferential Reading } \\
\text { Comprehension }\end{array}$ & $67,2 \%$ & $60 \%-69 \%$ & Fair \\
\hline 3 & $\begin{array}{l}\text { The students' reading } \\
\text { Comprehension } \\
\text { achievement }\end{array}$ & $70 \%-79 \%$ & Good \\
\hline
\end{tabular}

After the data has been analyzed, the researcher gets the results which are needed in this research. The result in the table 4.4 gives the reality about the students' reading comprehension achievement of the seventh class students at SMP Sunan Giri Cluring in 2013/2014 academic year. The students' reading comprehension 
achievement is categorized as good because they got $73,4 \%$ which is the score is in the interval between $70 \%-79 \%$

The range of reading comprehension that is achieved by the students ids from $67,2 \%$ up to $75,4 \%$. Based on the data analysis presented above, the students' highest achievement is the literal comprehension that is $75,4 \%$ which is categorized as good. This is because the students could understand the material without knowing all the meaning of words in a sentence to save the time. The analysis of test item showed that the students got many correct answers in literal comprehension

And for the inferential comprehension achievement is 67, 2 \%. It is categorized fair because is the lowest achievement that is gotten by the students. We can see that the students have a problem with the inferential comprehension

that related to their vocabulary. It is presented in the analysis of the test item that the students got many faults in the inferential comprehension items

In this research, the problem was faced by the seventh class students at SMP Sunan Giri Cluring in 2013/2014 academic year in inferential reading comprehension. It is happened because the students' inferential reading comprehension influenced by the vocabulary that they got. The way of the teacher in teaching vocabulary is considered as the weakness. The students will also get the problem with their comprehension if they cannot comprehend the inferential well and lack of vocabulary.

The teacher can add some context to teach vocabulary for the students so they can be familiar with the words. The teacher also can improve the students' reading comprehension by giving some tasks in any English textbook or supported books that appropriate for the students. The students can also read articles, English magazine or short stories to avoid the boredom in reading. Newnue (2011) said that reading for understanding is needed by the students to comprehend the relation between information and knowledge of the subject. By these ways, hopefully the students can gain much knowledge in comprehending reading text.

This finding shows that the students' reading comprehension achievement at SMP Sunan Giri Cluring for the seventh grade students in 2013/2014 academic year is good. They still cannot perform more than good because they have a problem in inferential reading comprehension

\section{E. Conclusion}

The result of the data analysis shows in general that the seventh class students at SMP Sunan Giri Cluring in 2013 / 2014 academic year can be concluded had good qualification $(73,4 \%$ ) on reading comprehension achievement of each indicator as follow

The seventh class students' achievement for literal reading comprehension at SMP Sunan Giri Cluring in 2013/2014 academic year was good $(75,4 \%)$. 
The seventh class students' achievement for inferential reading comprehension at SMP Sunan Giri Cluring in 2013/2014 academic year was fair $(67,2 \%)$.

The result above shows that literal reading comprehension was the easier for the students than inferential reading comprehension. The average score on the literal reading comprehension was higher than inferential reading comprehension. It was because the students could manage the time to understand a sentence without knowing all the meaning of words

This shows that the seventh class students of SMP Sunan Giri Cluring still need to improve their reading comprehension achievement especially for inferential reading comprehension achievement.

\section{F. References}

Bos, S.C and Vaughn, S.1991. Strategies for Teaching Students.Unites Stated of

American: Allyn and BaconNuttal, C.2012. Teaching Reading Skills in a Foreign Language. Boston: Heinemann.

Counter, S., Balaraman, P., \&Hochgraf. 1996. Strategies for Effective Teaching

A Handbook for Teaching Assistant. Mandison: University of Wisconsin.

Fairbain, G.J. and Winch, C. 1996. Reading Writing and Reasoning. A Guide for Students. Second Edition. Buckingham Philadelphia: Open University Press.

Grellet, F.1996. Developing Reading Skill. New York: Cambridge University Press.

McMillan, J. H.1992. Educational Research: Fundamental for the Consumer.New York: Harper Collins Publisher.

Wood, N. V.1991. Strategies for College Reading and Thinking. New York: McGraw-Hill, Inc.

Parrish, B.2007. Teaching Adult ESL (A Practical Introduction ) Hamline Univercity: McGraw-Hill ESL/ELT Published.

(http://www.usingmindmaps.com/what-is-at-mind-map.html Accessed on May 1,2014

(http://www.readingsuccesslab.com/glossary/improvreadingcomprehen sion.html) 
California State University. 2012. Definitions of Assesment. (Online). Available:http://www.csulb.edu/divisions/aa/gradundergrad/s enate/committess/asses sment/dev/info/what/ (23th June 2013)

Cambridge University Press. 2011. Definition of Informant. (Online). Available:http:dictionary.cambridge.org/dictionary/british/infor mant (23th June 2013).

Collin. 2012. Definitions of Informant. (Online). Available: http://www.collinsdictionary.com/dictionary/english/informant (23th June 2013)

Higher Learning commission. 2006. A Definition of Assessment. (Online). Available:http://www.uni.edu/assessment/definitionofassessme nt.shtml (23th June 2013)

Ipurangi, Te Kete. Definition of Student Achievement. (Online). Available: http://assessment.tki.org.nz/Overall-teacherjudgment/Definitions-of- achievement (23th June 2013)

Muhammad.2010. English for Young Learners. Banyuwangi: UNIBA

Newneu. 2011. Purpose for Comprehensive reading.(Online). Available:http://www.shvoomg.com/writing-andspeaking/copywriting/2099899-purpose-comprehensivereading/ (27th June 2013)

Owens, Jr. J. E. 2008. The Purpose of Reading. (Online). Available: http://www.education.com/reference/article/processreading/. (27 th June 2013)

Yossuke, Yosta. 2011. Definition Reading Comprehension. (Online). Available: $\quad$ http://yoyoi.blogspot.com/2011/06/definitionreading-comprehension.html (2th July 2013)

Yossuke, Yosta. 2011. Kinds of Reading Comprehension. (Online). Available: http://yoyoi.blogspot.com/2011/06/kinds-of-readingcomprehension.html (2nd July 2013) 